\title{
Wojciech Jaworski*
}

\section{Centrale syjonistyczne w Krakowie (1919-1939)}

Dzieje central syjonistycznych w Krakowie nie były przedmiotem samodzielnych prac, a stanowią część publikacji ukazujących żydowski ruch narodowy w Polsce w okresie międzywojennym. Historię syjonizmu w latach po I wojnie światowej przedstawia monografia Ezry Mendelsohna, która koncentruje się na zagadnieniach ideologiczno-doktrynalnych ${ }^{1}$. Jej swoistą kontynuację stanowi opracowanie Jacka Walickiego ${ }^{2}$.

Nie zachowały się akta wytworzone przez centrale partii syjonistycznych w Krakowie w okresie międzywojennym. Dlatego najważniejszymi źródłami archiwalnymi do ich dziejów są akta zespołów byłych urzędów administracji państwowej Starostwo Grodzkie Krakowskie (1919-1939) i Urząd Wojewódzki Krakowski (1920-1939) przechowywane w Archiwum Narodowym w Krakowie. Jednak stan zachowania akt obu zespołów i sposób ich sporządzania spowodował, że ich wartość informacyjna jest ograniczona. Drobne wzmianki do tematu znajdują się w zespole Ministerstwo Spraw Wewnętrznych w Warszawie (1918-1939) przechowywanym w Archiwum Akt Nowych w Warszawie. Głównymi źródłami do poznania dziejów central krakowskich są dwa czasopisma żydowskie wydawane w języku polskim z uwagi na zaawansowany proces asymilacji kulturowej miejscowych wyznawców judaizmu. „Nowy Dziennik” (1918-1939) pełnił rolę organu Organizacji Syjonistycznej Małopolski Zachodniej (OSMZ), a tygodnik „Trybuna Narodowa” (1934-1938) był pismem Unii Syjonistów-Rewizjonistów Małopolski Zachodniej i Śląska (US-RMZiŚl). Uzupełnieniem prasy

* dr; autor książek, artykułów, materiałów i recenzji naukowych oraz publikacji popularnonaukowych; zainteresowania badawcze: dzieje społeczno-polityczne ziem polskich w XIX i XX w. ze szczególnym uwzględnieniem historii Żydów; e-mail: wjaworski7@ gmail.com

1 Ezra Mendelsohn, Zionizm in Poland. The formative years 1915-1926, New Haven-London 1981.

${ }^{2}$ Jacek Walicki, Ruch syjonistyczny w Polsce w latach 1926-1930, Łódź 2005. 
krakowskiej jest dziennik warszawski „Nasz Przegląd” (1923-1939) związany z Organizacją Syjonistyczną w Polsce (OSwP).

Kraków na przełomie XIX i XX w. był jednym z ważniejszych ośrodków kształtowania się żydowskiego ruchu narodowego w świecie. Było to uwarunkowane położeniem w Galicji stanowiącej prowincję Cesarstwa Austro-Węgierskiego. Monarchia Habsburgów i jej stolica Wiedeń stanowiły do 1914 r. światowe centrum rozwoju syjonizmu. W 1883 r. powstało w Galicji stowarzyszenie Mikra Kodesz, które w 1887 r. przekształciło się w organizację Syjon. Po I Kongresie Syjonistycznym w 1897 r. stała się ona partia polityczną ${ }^{3}$.

Obok głównego nurtu żydowskiego ruchu narodowego w Galicji Zachodniej - Organizacji Syjonistycznej, na początku XX w. rozpoczęły działalność inne partie. Wraz z ukształtowaniem się wśród Żydów warstwy robotniczej powstał ruch syjonistów-socjalistów. W 1904 r. utworzono w Krakowie ogólnoaustriacką Żydowską Robotniczą Partię Socjalistyczną „Poalej Syjon”. Jednak w 1912 r. zaprzestała ona działalności ${ }^{4}$. Słabą aktywność wykazywała Organizacja Syjonistów-Ortodoksów „Histadruth Mizrachi” (Mizrachi), łącząca żydowską ideologię narodową z tradycyjnymi wartościami religijnymi.

Okres I wojny światowej przyniósł zmiany w ruchu syjonistycznym w Galicji Zachodniej. Jego aktywność zmalała. W 1917 r. wznowiła działalność Poalej Syjon. Dopiero w 1918 r., wraz z końcem działań wojennych nastąpiło ożywienie żydowskiego ruchu narodowego ${ }^{5}$.

Kres I wojny światowej, wzrost nastrojów narodowych i rewolucyjnych oraz rozpad mocarstw zaborczych sprawiły, że ruch syjonistyczny w byłej Galicji Zachodniej znalazł się w trudnym położeniu. Podstawowym problemem stało się samookreślenie wobec zachodzących zmian politycznych, w tym głównie powstających nowych organizmów państwowych. Upadek

${ }^{3}$ Filip Friedman, Rozwój żydowskiego ruchu narodowego w Galicji $i$ walka o prawa narodowe, [w:] Żydzi w Polsce odrodzonej. Działalność społeczna, gospodarcza, oświatowa i kulturalna, t. 1, pod red. Ignacego Schipera, Arjeha Tartakowera, Aleksandra Hafftki, Warszawa [1932], s. 396; Ignacy Schiper, Dzieje syjonizmu na ziemiach polskich (do 1918 r.), [w:] Żydzi..., t. 1, s. 526-527.

${ }^{4}$ Filip Friedman, Żydowski ruch robotniczy $w$ Galicji, [w:] Żydzi..., t. 1, s. 400; E. Mendelsohn, Zionism..., s. 24.

${ }^{5}$ Ibidem, s. 75-79; Ignacy Schiper, Żydzi galicyjscy w ostatnim roku pożogi wojen$n e j,[\mathrm{w}]: \dot{Z} y d z i \ldots$, t. 1, s. 420. 
dotychczasowych struktur administracyjnych państw zaborczych oraz olbrzymie trudności bytowe ludności powodowały wybuchy ekscesów i pogromów antyżydowskich.

W dniach 11-12 maja 1919 r. obradowała w Krakowie I Konferencja Krajowa OSMZ. W jej obradach wzięli udział delegaci partii Hitachduth i Mizrachi, którzy uczestniczyli również w następnych zjazdach do chwili zerwania współpracy organizacyjnej. Formalnie doszło wówczas do ukształtowania się krakowskiej centrali ogólnosyjonistycznej, która obejmowała zasięgiem byłą Galicję Zachodnią po rzekę San na wschodzie. Jej organem została wówczas wybieralna Rada Partyjna. W terenie komitety lokalne partii tworzyły początkowo słabo sformalizowane grupy działaczy. Centrala dzielnicowa miała koordynować działalność partii na tym obszarze oraz wyznaczać zadania do realizacji przez jej oddziały. Na czele centrali stanął postępowy rabin dr Ozjasz Abraham Thon. Obrady zjazdu poświęcono: działalności delegacji żydowskiej na konferencji pokojowej w Paryżu, zagadnieniom palestyńskim, aktualnemu położeniu Żydów w Polsce i ich przyszłej autonomii narodowej, a także gminom wyznaniowym. Władze państwowe wezwano do przeciwdziałania pogromom. Głównymi celami działalności syjonistów miały być produktywizacja (odejście od pracy w handlu i usługach do produkcji, głównie w rolnictwie) Żydów w Palestynie i ich szkolenie zawodowe w krajach dotychczasowego osiedlenia. Dominującymi formami własności w Palestynie w przyszłości byłyby społeczna (spółdzielcza) i narodowa (państwowa). Żydowski Fundusz Narodowy „Keren Kajemet Le“Israel” miał wykupywać ziemię w Palestynie dla osadnictwa żydowskiego. Autonomia w Polsce miała się oprzeć o strukturę Żydowskiej Rady Narodowej, która stanowiłaby wybieralną, najwyższą ich reprezentację. Podlegać jej miały rady okręgowe (wojewódzkie) i miejscowe, które zastapiłyby gminy wyznaniowe. Podczas konferencji podkreślano znaczenie języka hebrajskiego dla ruchu syjonistycznego i przyszłego państwa żydowskiego. Dr Ignacy Schwartzbart przedstawił sprawę zjednoczenia krakowskiej centrali partii z warszawską, które uzyskało prawdopodobnie aprobatę delegatów. Głównym wrogiem politycznym ogólnych syjonistów byli asymilatorzy, których miano zwalczać wspólnie z: Mizrachi, Poalej Syjon, Żydowską Partią Socjaldemokratyczną i ortodoksamí.

${ }^{6}$ „Nowy Dziennik” 1919, nr 86 (13 maja), s. 1; nr 87 (14 maja), s. 1-2; nr 88 (15 maja), s. 3; nr 93 (20 maja), s. 1. 
Pod koniec 1919 i w 1920 r. nastapił spadek aktywności syjonistycznych organizacji politycznych w związku z toczącą się wojną polsko-radziecką. Wzrosły wówczas w społeczeństwie i aparacie państwowym nastroje nacjonalistyczne i ksenofobiczne, uwarunkowane zagrożeniem bytu państwowego. W działalności politycznej Żydów widziano niebezpieczeństwo wynikające z możliwości poparcia przez nich dążeń Rosji Radzieckiej. Dopiero pod koniec 1920 r. doszło do uspokojenia nastrojów antyżydowskich.

W lipcu 1920 r. na konferencji Rady Ambasadorów Ligi Narodów zapadła decyzja o podziale Śląska Cieszyńskiego i przyznaniu jego wschodniej części Polsce. Pozwoliło to na przystąpienie działających tam syjonistów do centrali krakowskiej. Ważnym ośrodkiem żydowskiego ruchu narodowego w tym regionie było Bielsko.

W dniach 27-28 marca 1921 r. odbyła się w Krakowie II Konferencja Krajowa Organizacji Syjonistycznej Małopolski Zachodniej i Śląska (OSMZiŚl). Przybyli na nią delegaci z pozostałych dzielnic. Obrady konferencji koncentrowały się na sprawach wewnątrzorganizacyjnych. Domagano się utworzenia stowarzyszeń rzemieślników żydowskich i spółdzielni spożywczych. Ujawniły się tendencje do unifikacji z syjonistami z byłego Królestwa Polskiego i Białostocczyzny, których wyrazicielem był dr Chaim Hilfstein. W związku z tym podjęto uchwałę o podporządkowaniu się władz centrali krakowskiej Centralnemu Komitetowi OSwP z siedzibą w Warszawie, z zachowaniem autonomii wewnętrznej, oraz zwoływaniu wspólnych zjazdów ogólnych syjonistów z obu dzielnic. Na stanowisko prezesa OSMZiŚl wybrano O. A. Thona?

Na V Zjeździe OSwP na przełomie lipca i sierpnia 1921 r. zapadło postanowienie o formalnym zjednoczeniu central krakowskiej i warszawskiej, które zostało jednak odrzucone prawdopodobnie przez Radę Partyjną OSMZiŚl.

Na posiedzeniu Rady Partyjnej OSMZiŚl w Krakowie 6 listopada 1921 r. nie powrócono już do kwestii zjednoczenia z centralą warszawską. Uchwalono natomiast rezolucję o reorganizacji wewnętrznej. W związku z nikłą aktywnością większości członków partii postanowiono przeprowadzić wybory zarządów skupiających ich komitetów lokalnych. Aby zintegrować działalność oddziałów miejscowych, zdecydowano utworzyć struktury po-

7 „Nowy Dziennik” 1921, nr 84 (1 kwietnia), s. 5; nr 87 (4 kwietnia), s. 4; „Nowy Dziennik" 1926, nr 166 (25 lipca), s. 3. 
średnie między nimi a centralą - komitety okręgowe w: Bielsku, Jarosławiu, Jaśle, Nowym Sączu, Rzeszowie, Sanoku i Tarnowie. Zwiększenia wpływów społecznych ogólnych syjonistów upatrywano w intensyfikacji pracy propagandowej oraz rozwoju działalności stowarzyszeń kulturalno-oświatowych. Zamierzano podjąć agitację na rzecz masowego wykupu szekli potwierdzenie wpłacenia ustalonej kwoty na rzecz Światowej Organizacji Syjonistycznej (ŚSOS) ${ }^{8}$.

Wraz z przyłączeniem części Górnego Śląska do Polski w czerwcu 1922 r. miejscowi syjoniści przystapili do centrali krakowskiej.

Pierwsza powojenna konferencja Mizrachi w Krakowie odbyła się 13 maja 1919 r. Potwierdzono na niej wznowienie działalności partii w byłej Galicji. Na czele komitetu okręgowego partii, który podlegał centrali warszawskiej, stanął Mojżesz Horowitz 9 . Partia miała jednak współdziałać dalej z ogólnymi syjonistami w ramach centrali krakowskiej OSMZ.

Dnia 5 maja 1919 r. odbył się w Krakowie zjazd Frakcji Ludowej Organizacji Syjonistycznej „Ceirej Syjon” z byłej Galicji Zachodniej, łączącej syjonizm z umiarkowanym socjalizmem ${ }^{10}$. Odłam lewicowy partii przyjął program socjalistyczny, a prawicowy przekształcił się w Syjonistyczną Partię Pracy „Hitachduth”, której członkowie wystapili z Organizacji Syjonistycznej. W 1922 r. nowa partia utworzyła w Krakowie komitet rejonowy utrzymujący współpracę organizacyjną z OSMZiŚl11.

W latach 1919-1920 nastąpił rozłam w Poalej Syjon na frakcję przywiązaną do idei syjonizmu i zradykalizowaną większość zdominowaną przez komunistów. W dniach 15-16 kwietnia 1921 r. odbył się w Krakowie zjazd konstytucyjny pierwszej frakcji i powołano do życia Żydowską Niezawisłą Socjaldemokratyczną Partię Robotniczą Poalej Syjon w Polsce. Wobec słabości nowego ugrupowania w Małopolsce Zachodniej wkrótce przeniesiono siedzibę jej zarządu z Krakowa do Warszawy ${ }^{12}$.

Od 1919 r. podejmowano próby zjednoczenia ogólnosyjonistycznych central krakowskiej i warszawskiej. Dnia 2 grudnia 1923 r. odbyła się

8 „Nowy Dziennik” 1921, nr 292 (9 listopada), s. 4; nr 293 (10 listopada), s. 5.

9 „Nowy Dziennik” 1919, nr 93 (20 maja), s. 3.

${ }^{10}$ „Nowy Dziennik” 1919, nr 79 (6 maja), s. 3.

${ }^{11}$ AAN, Ministerstwo Spraw Wewnętrznych w Warszawie, sygn. 1062 (2/9/0/2.2/I 1062), k. 341; E. Mendelsohn, Zionism..., s. 237-238.

12 „Nowy Dziennik” 1921, nr 104 (22 kwietnia), s. 5; E. Mendelsohn, Zionism..., s. 232. 
w Krakowie IV Konferencja Krajowa OSMZiŚl. Uchwalono na niej między innymi rezolucję wzywającą Centralny Komitet partii do szukania porozumienia z OSwP w celu zwołania ogólnopolskiej konferencji palestyńskiej. Prezesem partii został O. A. Thon, który zastapił C. Hilfsteina wybranego prawdopodobnie przez III konferencję krajową w 1922 r. Obrady konferencji skupiły się na sprawach propagandowo-wychowawczych. Planowano wspierać ruch chalucowy (przygotowanie ideologiczne i zawodowe młodzieży do emigracji do Palestyny). Potępiono numerus clausus (ograniczenie liczby studentów żydowskich na wyższych uczelniach w Polsce) i pogromy w Niemczech ${ }^{13}$.

W podobnej atmosferze przebiegała V Konferencja Krajowa OSMZiŚ1, która obradowała w Krakowie 23 marca 1924 r. Zasadniczy nacisk położono na wzmocnienie współpracy centrali z komitetami lokalnymi partii ${ }^{14}$.

W lipcu 1924 r. powrócono do kwestii unifikacji w Polsce dzielnicowych Organizacji Syjonistycznych. Inicjatorem zjednoczenia był Ignacy Schwartzbart z centrali krakowskiej. Przed posiedzeniem Rady Partyjnej OSMZiŚl opublikował artykuł Problemy syjonizmu w Polsce, w którym stwierdził, że potrzebne jest połączenie central partii ogólnosyjonistycznych z: Krakowa, Lwowa, Warszawy i Wilna oraz ustanowienie wspólnego komitetu wykonawczego w Warszawie i podległych mu komitetów wojewódzkich. Miała powstać także Żydowska Rada Narodowa powołana w wyniku ogólnopolskiej konferencji, która objęłaby wszystkie stronnictwa syjonistyczne. Potrzebę zjednoczenia ruchu syjonistycznego podkreślił I. Schwartzbart na posiedzeniu Rady Partyjnej OSMZiŚ1 14 września 1924 r. W konferencji zjednoczeniowej Organizacji Syjonistycznych 21 września 1924 r. w Krakowie wzięli udział z ramienia centrali krakowskiej dr Szymon Feldblum, C. Hilfstein i O. A. Thon. Centrala krakowska uznawała po I wojnie światowej swoisty prymat OSwP. Wobec zaistniałych rozbieżności, aby nie doprowadzić do zerwania rozmów, zdecydowano się na federacyjny charakter unifikacji. Dotychczasowe organy dzielnicowe Organizacji Syjonistycznych miały posiadać charakter autonomiczny ${ }^{15}$.

${ }^{13}$ ANK, Urząd Wojewódzki Krakowski, sygn. 29/206/534 (dawna sygn. UWKr 265), k. 121; „Nowy Dziennik” 1923, nr 290 (3 grudnia), s. 3; nr 291 (4 grudnia), s. 3.

${ }^{14}$ ANK, Urząd Wojewódzki Krakowski, sygn. 29/206/535 (dawna sygn. UWKr 266), k. 231.

15 „Nowy Dziennik” 1924, nr 161 (19 lipca), s. 5; nr 212 (18 września), s. 6; „Nasz Przegląd"1924, nr 266 (22 września), s. 3. 
7 grudnia 1924 r. odbyła się w Tarnowie VI Konferencja Krajowa OSMZiŚl. Omawiano na niej potrzebę wzmocnienia działalności partii i sprawę zjednoczenia z pozostałymi centralami syjonistycznymi w Polsce. C. Hilfstein stwierdził, że dąży do przekształcenia dzielnicowych partii w jednolitą strukturę, ale władze central lwowskiej i warszawskiej uważały unifikację za przedwczesna, a także domagały się jej przeprowadzenia na zasadach federalistycznych. Uczestniczący w obradach przedstawiciel OSwP Maksymilian Apolinary Hartglas poparł stanowisko C. Hilfsteina, ale nie określił charakteru zjednoczenia. Konferencja przyjęła stanowisko pośrednie między prostym a federacyjnym modelem unifikacji partii ogólnosyjonistycznych. Zakładano utworzenie ogólnopolskiej Organizacji Syjonistycznej i jej organów, jednak z zachowaniem dotychczasowych central dzielnicowych.

Członkowie Hitachduth biorący udział w VI Konferencji Krajowej OSMZiŚl opowiedzieli się za federacyjnym kształtem ruchu syjonistycznego w Polsce, ale zjednoczenia ogólnych syjonistów nie uważali za początek konsolidacji stronnictw narodowych. Dążyli do powstania tylko związku wszystkich federacji syjonistycznych i uznali, że nie mogli ponosić odpowiedzialności za decyzje konferencji, co było zapowiedzią zerwania więzów organizacyjnych z OSMZiŚl. Prezesem centrali krakowskiej wybrano ponownie O. A. Thona ${ }^{16}$.

3 stycznia 1926 r. odbyła się w Krakowie VII Konferencja Krajowa OSMZiŚl. Podczas obrad stwierdzono, że w partii panuje marazm. I. Schwartzbart wskazał na aktywność syjonistycznych organizacji młodzieżowych, słabość kobiecych oraz konieczność zjednoczenia dzielnicowych Organizacji Syjonistycznych, któremu przeszkadzają ambicje polityków. Protestowano przeciwko planom przekształcenia ŚOS w federację, w której Organizacja Syjonistyczna stałaby się jedną z frakcji. Domagano się ułatwień przez brytyjskie władze mandatowe kolonizacji wiejskiej w Palestynie. Poparto stanowisko Komitetu Wykonawczego ŚOS w sprawie współpracy między Żydami a Arabami w Palestynie. Uznano, że autonomia dla Arabów nie ograniczyłaby możliwości utworzenia Państwa Izrael. Wyrażono zadowolenie z unifikacji dzielnicowych Organizacji Syjonistycznych w Polsce. Poparto porozumienie zawarte między Kołem Żydowskim

16 „Nowy Dziennik” 1924, nr 277 (11 grudnia), s. 3-4; nr 278 (12 grudnia), s. 3; nr 279 (13 grudnia), s. 3-4. 
w Sejmie a rządem polskim i oczekiwano, że zrealizuje je premier Aleksander Skrzyński. Uznano, że rozporządzenie prezydenta w sprawie wyborów do władz gmin wyznaniowych żydowskich nie w pełni odpowiada stronnictwom syjonistycznym ze względu na wysoki cenzus wieku i pozbawienie praw wyborczych kobiet, ale stanowi krok w kierunku ich demokratyzacji. Same gminy powinny pełnić funkcje nie tylko religijne, ale także kulturalno-społeczne. Na konferencji doszło do utworzenia nowego stanowiska kierowniczego w partii. Jej prezesem honorowym, stojącym na czele Rady Partyjnej, wybrano O. A. Thona, a prezesem nowo utworzonego Centralnego Komitetu dr. Samuela Wahrhaftiga ${ }^{17}$. Działacze syjonistyczni młodszego pokolenia chcieli w ten sposób osłabić dominującą pozycję O. A. Thona w partii.

W 1923 r. doszło do konfliktu w Komitecie Wykonawczym ŚOS, który zakończył się wystąpieniem z niego Włodzimierza Żabotyńskiego. Na zjeździe w Paryżu w 1925 r. utworzył on Związek Syjonistów-Rewizjonistów, który pozostawał w strukturze ŚOS. Pierwsze grupy syjonistów-rewizjonistów rozpoczęły w Polsce działalność w 1925 r., w środowisku zradykalizowanej młodzieży akademickiej. W marcu 1926 r. ujawniła się w Krakowie w Organizacji Syjonistycznej taka grupa, którą tworzyli działacze Syjonistycznej Organizacji Akademickiej „Haszachar” Bronisław Mender Ber, Jakub Bernard Damm i Aron Koplowicz ${ }^{18}$.

Od połowy lat 20. zaczęło maleć znaczenie Mizrachi, która była majoryzowana przez Organizację Syjonistyczną. Skłoniło to działaczy do usamodzielnienia się w dzielnicy krakowskiej, bowiem do tego czasu jej przedstawiciele brali udział w zjazdach OSMZiŚl. I Krajowa Konferencja Mizrachi Małopolski Zachodniej i Śląska obradowała w Krakowie 24 maja 1925 r. Utworzono na niej komitet dzielnicowy partii i postanowiono o zerwaniu współpracy organizacyjnej z OSMZiŚl. Zażądano certyfikatów (dokument umożliwiający emigrację do Palestyny) dla stanu średniego i prowadzenia kolonizacji w Palestynie zgodnie z zasadami religii mojżeszowej. Protesto-

${ }^{17}$ „Nowy Dziennik” 1926, nr 4 (6 stycznia), s. 1-3; nr 5 (7 stycznia), s. 5-6; nr 6 (9 stycznia), s. 5.

${ }^{18}$ ANK, Starostwo Grodzkie Krakowskie, sygn. 29/218/133 (dawna sygn. StGKr 133), k. 34; „Nowy Dziennik” 1926, nr 57 (11 marca); s. 4; E. Mendelsohn, Zionism..., s. 317-318. 
wano przeciwko ograniczeniom emigracji żydowskiej do niej przez brytyjskie władze mandatowe ${ }^{19}$.

III Konferencja Rejonowa Hitachduth Małopolski Zachodniej i Śląska obradowała w Krakowie w dniach 31 maja - 1 czerwca 1925 r. Wskazano, że kolonizacja Palestyny powinna być oparta o emigrację robotników. Prezesem komitetu rejonowego partii wybrano dr. Ottona Menasche. Wpływy Hitachduth w dzielnicy krakowskiej były wówczas znikome ${ }^{20}$.

3 stycznia 1926 r. w Krakowie zebrała się Rada Partyjna Hitachduth Małopolski Zachodniej i Śląska. Podjęto rezolucję o współpracy z innymi partiami syjonistycznymi w dzielnicy krakowskiej w zakresie finansów i emigracji do Palestyny w ramach funduszy narodowych. Poparto rozwój szkolnictwa i kultury hebrajskiej. Wezwano członków partii do wstępowania do powstającej Ligi Pomocy Pracującym w Palestynie, utworzenia organizacji młodzieżowej Gordonia oraz uznania tylko jednej organizacji chalucowej w Polsce - Hapoel Hacair ${ }^{21}$.

Aby zakończyć rozbicie dzielnicowe Hitachduth, w dniach 5-7 marca 1926 r. odbył się w Krakowie zjazd delegatów central z Krakowa, Lwowa i Warszawy. Podjął on uchwałę o unifikacji struktur dzielnicowych i utworzeniu centrali w Warszawie. Wybrano wspólną Radę Partyjną z O. Menasche jako prezesem ${ }^{22}$.

W dniach 31 października - 1 listopada 1926 r. obradowała w Krakowie VIII Konferencja Krajowa OSMZiŚl. O. A. Thon oskarżył przywódców OSwP o rozbicie ogólnopolskiej centrali ogólnosyjonistycznej. Uznał, że unifikacja dzielnicowych partii była konieczna, ale wówczas niemożliwa do zrealizowania. Uczestnicy konferencji domagali się wprowadzenia dyscypliny w komitetach lokalnych oraz zwrócili się do Komitetu Wykonawczego ŚSS o unifikację organizacji młodzieżowych działających w jej ramach. Potępiono również aktywność frakcyjną w światowej strukturze i wezwano Centralny Komitet partii do zainicjowania współpracy Organizacji Syjonistycznych z pozostałymi federacjami. Na czele Rady Partyjnej

\footnotetext{
19 „Nowy Dziennik” 1925, nr 118 (27 maja), s. 3; nr 121 (30 maja), s. 3.

${ }^{20}$ „Nowy Dziennik” 1925, nr 125 (6 czerwca), s. 5; nr 126 (7 czerwca), s. 3.

${ }^{21}$ „Nowy Dziennik” 1926, nr 5 (7 stycznia), s. 6.

${ }^{22}$ „Nowy Dziennik” 1925, nr 59 (13 marca), s. 11.
} 
pozostał O. A. Thon, a prezesem Centralnego Komitetu wybrano dr. Judę Zimmermanna ${ }^{23}$.

W Krakowie 13 marca 1927 r. odbyło się posiedzenie Rady Partyjnej OSMZiŚl. Wskazano, że część oddziałów OSwP w południowych powiatach województw kieleckiego i lubelskiego chciała przystapić do centrali krakowskiej. Rada Partyjna wyraziła poparcie dla pertraktacji w sprawie zjednoczenia syjonistycznych organizacji młodzieżowych oraz potępiła tworzenie nowych i odejście od zasad bezpartyjności w organizacjach chalucowych $^{24}$.

W dniach 31 października - 1 listopada 1927 r. obradowała w Krakowie IX Konferencja Krajowa OSMZiŚl. Mówiono na niej o położeniu ekonomicznym ludności żydowskiej w Polsce, sytuacji w gminach wyznaniowych i ruchu syjonistycznym. Prezesem Rady Partyjnej pozostał O. A. Thon, a prezesem Centralnego Komitetu wybrano S. Feldbluma ${ }^{25}$.

Obrady X Konferencji Krajowej OSMZiŚl odbyły się w dniach 31 października - 2 listopada 1928 r. w Krakowie. I. Schwartzbart wskazał na brak unifikacji ruchu syjonistycznego w Polsce. Dyskutowano o trudnym położeniu ekonomicznym ludności żydowskiej. Wyrażono radość z powodu sukcesu w wyborach do organów gmin wyznaniowych. Prezesem Rady Partyjnej został ponownie O. A. Thon, a Centralnego Komitetu - I. Schwartzbart ${ }^{26}$.

Na posiedzeniu Rady Partyjnej OSMZiŚl 30 maja 1929 r. w Krakowie wyrażono radość z powodu porozumienia między frakcjami syjonistycznymi w dzielnicach lwowskiej i warszawskiej oraz ubolewanie ze względu na niedojście do skutku ogólnopolskiego zjazdu syjonistycznego. Domagano się kontynuowania starań o zjednoczenie ruchu syjonistycznego i unifikację organizacji młodzieżowych ${ }^{27}$.

Obrady XI Konferencji Krajowej OSMZiŚl odbyły się w Krakowie w dniach 5-7 stycznia $1930 \mathrm{r}$. Wziął w niej udział członek przewodniczący egzekutywy Agencji Żydowskiej Nahum Sokołow. O. A. Thon omówił dys-

${ }^{23}$ „Nowy Dziennik” 1926, nr 245 (4 listopada), s. 1-2; nr 247 (6 listopada), s. 5; nr 248 (7 listopada), s. 5; nr 249 (8 listopada), s. 7.

${ }^{24}$ „Nowy Dziennik” 1927, nr 68 (16 marca), s. 6.

${ }^{25}$ „Nowy Dziennik” 1927, nr 290 (3 listopada), s. 2.

${ }^{26}$ ANK, Starostwo Grodzkie Krakowskie, sygn. 29/218/134 (dawna sygn. StGKr 134), k. 73; „Nowy Dziennik” 1928, nr 295 (3 listopada), s. 2; nr 296 (4 listopada), s. 5; nr 297 (5 listopada), s. 5-6; nr 298 (6 listopada), s. 3; nr 302 (10 listopada), s. 5.

27 „Nowy Dziennik” 1929, nr 149 (5 czerwca), s. 6; nr 153 (9 czerwca), s. 10. 
kryminację Żydów w urzędach i instytucjach państwowych. I. Schwartzbart wskazał na brak unifikacji dzielnicowych partii ogólnosyjonistycznych. Aby przeciwstawić się wpływom lewicy syjonistycznej wśród młodzieży, postanowiono utworzyć ogólnosyjonistyczną organizację Bnej Syjon. W kwestiach palestyńskich złożono hołd osadnikom żydowskim zabitym w Palestynie przez Arabów, a także postanowiono wspierać wyjazdy do niej przez utworzenie Biura Emigracyjnego w Krakowie. Domagano się wzmocnienia działań na rzecz funduszy narodowych „Keren Hajesod” i „Keren Kajemeth Le'Israel". Prezesem honorowym partii wybrano O. A. Thona, a Centralnego Komitetu - I. Schwartzbarta, przy sprzeciwie ze strony syjonistów-rewizjonistów ${ }^{28}$.

Słabość organizacyjna Mizrachi wynikała w części z jej doktryny łączącej tradycyjne wartości z narodowymi. Większość Żydów o konserwatywnych przekonaniach popierała Centralną Organizację Żydów Ortodoksów „Agudas Israel”. Chcąc temu przeciwdziałać, obradująca w Krakowie 13 czerwca 1926 r. Rada Partyjna Mizrachi Małopolski Zachodniej i Śląska domagała się zwołania zjazdów okręgowych w: Bielsku, Jaśle, Rzeszowie, Sanoku i Tarnowie, które miały zaktywizować oddziały miejscowe. Postulowano rozwój kultury, oświaty i ruchu chalucowego w duchu doktryny partii. Prezesem komitetu dzielnicowego partii wybrano rabina dr. Samuela Hirschfelda ${ }^{29}$.

II Konferencja Krajowa Mizrachi Małopolski Zachodniej i Śląska odbyła się w Krakowie na początku stycznia 1928 r. Prezesem komitetu dzielnicowego wybrano ponownie S. Hirschfelda ${ }^{30}$. Na III konferencji krajowej partii w Krakowie 12 stycznia 1930 r. omawiano głównie kwestie palestyńskie. Domagano się propagowania powstałego w 1929 r. partyjnego światowego funduszu narodowego „Keren Erec Israel Hadati” oraz rozwoju oświaty i kultury w duchu partyjnym. Podjęto uchwałę o utworzeniu ogólnopolskiej centrali Mizrachi ${ }^{31}$.

${ }^{28}$ ANK, Urząd Wojewódzki Krakowski, sygn. 29/206/541 (dawna sygn. UWKr 272), k. 23; „Nowy Dziennik” 1930, nr 8 (9 stycznia), s. 6-7; nr 9 (10 stycznia), s. 6-7; nr 10 (11 stycznia), s. 6; nr 11 (12 stycznia), s. 5; nr 12 (13 stycznia), s. 6; nr 13 (14 stycznia), s. 3.

${ }^{29}$ AAN, Ministerstwo Spraw Wewnętrznych w Warszawie, sygn. 961 (2/9/0/2.2/I 961),

k. 231; „Nowy Dziennik” 1926, nr 140 (24 czerwca), s. 6.

${ }^{30}$ „Nowy Dziennik” 1928, nr 6 (6 stycznia), s. 4.

31 „Nowy Dziennik” 1930, nr 25 (30 stycznia), s. 6; nr 26 (31 stycznia), s. 4; nr 27 (1 lutego), s. 7. 
Pomimo prób zjednoczenia Hitachduth działały trzy dzielnicowe struktury. W Krakowie był nią formalnie niezależny komitet rejonowy, związany w rzeczywistości z OSMZiŚl. Obradująca w Krakowie 30 czerwca 1926 r. IV Konferencja Rejonowa Hitachduth wybrała prezesem komitetu O. Menasche. Omawiano sprawy pracy kulturalnej i oświatowej. Podkreślono rolę funduszy narodowych w budowie państwa żydowskiego w Palestynie ${ }^{32}$.

W drugiej połowie lat 20. zaczęły rosnąć w dzielnicy krakowskiej wpływy Hitachduthu. V konferencja rejonowa partii odbyła się w Krakowie w dniach 19-20 listopada 1927 r. Podjęto na niej decyzję o utworzeniu dzielnicowego Centralnego Komitetu Hitachduthu i zerwaniu współpracy organizacyjnej z OSMZiŚl. Podkreślono konieczność rozwoju pracy kulturalnej w ramach Gordonii, wspierania finansowego „Keren Hajesod”, poparcia dla organizacji młodzieżowej „Ezra” i ruchu chalucowego ${ }^{33}$.

Kolejna VI Konferencja Krajowa Hitachduth Małopolski Zachodniej i Śląska obradowała w Krakowie 28 października 1928 r. Prezesem egzekutywy wybrano dr. Gur Arjeh Terło. Wskazano, że obecnym celem partii było utworzenie związków zawodowych o cechach narodowych. Podkreślono konieczność konsolidacji ruchu syjonistycznego na rzecz wzmocnienia budowy państwa żydowskiego w Palestynie. Wyrażono radość z powodu rozwoju ruchu chalucowego w ramach Gordonii ${ }^{34}$.

Wiosną 1929 r. nastąpiło w Palestynie zjednoczenie stronnictw Ahudat Haawodat i Hapoel Hacair, które były odpowiednikami działających w Polsce Hitchaduth i Poalej Syjon-Prawicy. Rada Partyjna Hitachduth Małopolski Zachodniej i Śląska 9 czerwca 1929 r. sprzeciwiła się unifikacji z Poalej Syjon-Prawicą ${ }^{35}$. VII konferencja krajowa partii obradująca w Krakowie 3 listopada 1929 r. była poświęcona rozwojowi ruchu chalucowego, oświaty i kultury hebrajskiej oraz poszerzeniu wpływów społecznych sy-

32 „Nowy Dziennik” 1926, nr 146 (2 lipca), s. 5.

33 „Nowy Dziennik” 1927, nr 308 (21 listopada), s. 10.

${ }^{34}$ AAN, Ministerstwo Spraw Wewnętrznych w Warszawie, sygn. 962 (2/9/0/2.2/I 962), k. 141; ANK, Starostwo Grodzkie Krakowskie, sygn. 29/281/134 (dawna sygn. StGKr 134), k. 23; „Nowy Dziennik” 1928, nr 294 (2 listopada), s. 7.

${ }^{35}$ ANK, Starostwo Grodzkie Krakowskie, sygn. 29/218/108 (dawna sygn. StGKr 108), k. 52 . 
jonistów. Nowym prezesem Centralnego Komitetu wybrano inż. Bernarda Zimmermanna $^{36}$.

Druga połowa lat 20. była okresem spadku znaczenia Poalej Syjon-Prawicy. 25 listopada 1928 r. odbyła się w Krakowie Konferencja Krajowa Poalej Syjon-Prawicy Małopolski Zachodniej i Śląska oraz Zagłębia Dąbrowskiego. Zjazd zakończył się wybraniem wspólnego Centralnego Komitetu Poalej Syjon-Prawicy dzielnicy krakowskiej i Zagłębia Dąbrowskiego, na którego czele stanął Chaskiel Freiberg ${ }^{37}$. Było to przejawem zanikania dawnych podziałów z czasów zaborów, bowiem oddziały partii w Zagłębiu Dąbrowskim początkowo podlegały centrali warszawskiej, a potem łódzkiej.

W dniach 21-22 lutego 1931 r. odbyła się w Krakowie XII Konferencja Krajowa OSMZiŚl. Jej głównym tematem była unifikacja partii ogólnosyjonistycznych w Polsce. Polecono Centralnemu Komitetowi partii ponowne podjęcie kroków w celu doprowadzenia do zjednoczenia. Zjazd domagał się utrzymania kontaktów ze wszystkimi młodzieżowymi organizacjami ogólnosyjonistycznymi oraz zorganizowania $\mathrm{w}$ ramach związku ogólnosyjonistycznego młodzieży starszej. Poddano krytyce syjonistów-rewizjonistów. Omawiano kwestię emigrantów i ich szkolenia zawodowego. Miano prowadzić akcję propagandową na rzecz funduszy narodowych. Prezesem Rady Partyjnej wybrano O. A. Thona, a Centralnego Komitetu I. Schwartzbarta ${ }^{38}$.

W czasie obrad XIII Konferencji Krajowej OSMZiŚl w dniach 5-6 stycznia 1932 r. w Krakowie wyrażono zadowolenie z utworzenia w ramach ŚOS Światowego Związku Ogólnych Syjonistów (ŚZwOS) oraz domagano się utrzymania jej jedności, której zagrażała secesja syjonistów-rewizjonistów. Zamierzano wzmocnić ruch ogólnosyjonistyczny w Polsce i działać na rzecz rozwoju organizacji młodzieżowej Hanoar Haiwri. Krytykowano ograniczenie emigracji robotników i chaluców do Palestyny, a rozwój stanu średniego. Podkreślono rolę funduszy narodowych. O. A. Thon skrytykował charakter

${ }^{36}$ ANK, Urząd Wojewódzki Krakowski, sygn. 29/206/540 (dawna sygn. UWKr 271), k. 234; „Nowy Dziennik” 1929, nr 298 (7 listopada), s. 3.

${ }^{37}$ ANK, Starostwo Grodzkie Krakowskie, sygn. 29/218/134 (dawna sygn. StGKr 134), k. 98.

${ }^{38}$ ANK, Urząd Wojewódzki Krakowski, sygn. 29/206/544 (dawna sygn. UWKr 275), k. 55; „Nowy Dziennik” 1931, nr 56 (26 lutego), s. 6; nr 59 (1 marca), s. 4; nr 60 (2 marca), s. 6 . 
rządów w Polsce i wskazał nazbyt wysokie obciążenie podatkowe Żydów, którzy nie są wspierani przez państwo. Wyrażono zaufanie dla parlamentarnego Koła Żydowskiego. Prezesem honorowym partii wybrano O. A. Thona, a egzekutywy J. Zimmermanna, bowiem I. Schwartzbart był wówczas zaangażowany w pracach ŚSOS ${ }^{39}$.

7 maja 1933 r. obradowała w Krakowie XIV Konferencja Krajowa OSMZiŚl. Omawiano trudne położenie ludności żydowskiej w Niemczech i konieczność przyjścia jej z pomocą oraz kwestie odbudowy państwa żydowskiego w Palestynie i potrzebę uwolnienia do niej imigracji przez brytyjskie władze mandatowe. I. Schwartzbart stwierdził, że w odbudowie państwa żydowskiego musi istnieć równowaga pracy i kapitału. Podkreślił rolę funduszy narodowych. Postulował jednak zwiększenie liczby emigracji dla stanu średniego, a także emigrację uciekinierów z Niemiec do Palestyny przez Biuro Palestyńskie w Krakowie. Za niezbędne uznał działanie ŚZwOS w ramach ŚSS, ale jednocześnie poparł światową centralę i kongresy syjonistyczne jako najważniejsze organy żydowskiego ruchu narodowego. Wyrażono radość z okazji zjednoczenia organizacji młodzieżowych Agudath Hanoar Haiwri „Akiba” i Hanoar Hacioni. Prezesem Rady Partyjnej wybrano O. A. Thona, Centralnego Komitetu mgr. Leona Salpetera ${ }^{40}$.

Dnia 14 stycznia 1934 r. odbyło się w Krakowie posiedzenie Rady Partyjnej OSMZiŚl. L. Salpeter omówił sprawę aktywnego udziału partii w pracach ŚZwOS, w którym narastały tendencje odśrodkowe. W przyjętych deklaracjach domagano się przywrócenia dyscypliny w ŚZwOS, przyjęcia przez niego programu oraz wyrażono poparcie dla zjednoczenia ogólnych syjonistów w Polsce i świecie ${ }^{41}$.

18 lutego 1934 r. obradowała w Krakowie XV Konferencja Krajowa OSMZiŚl. O. A. Thon mówił o konieczności konsolidacji ruchu syjonistycznego - stopniowej likwidacji frakcji i partii. Głównym zadaniem Organizacji Syjonistycznej miało być wychowanie ludności żydowskiej w duchu bezpartyjnej jedności narodowej. I. Schwartzbart podkreślił w swym wy-

${ }^{39}$ ANK, Urząd Wojewódzki Krakowski, sygn. 29/206/546 (dawna sygn. UWKr 277), k. 27; „Nowy Dziennik” 1932, nr 8 (8 stycznia), s. 2; nr 9 (9 stycznia), s. 3; nr 14 (14 stycznia), s. 6; nr 15 (15 stycznia), s. 6; nr 21 (21 stycznia), s. 4.

${ }^{40}$ ANK, Urząd Wojewódzki Krakowski, sygn. 29/206/548 (dawna sygn. UWKr 279), k. 143; „Nowy Dziennik” 1933, nr 128 (11 maja), s. 5-6; nr 134 (17 maja), s. 7-8; nr 135 (18 maja), s. 7.

${ }^{41}$ „Nowy Dziennik” 1934, nr 18 (18 stycznia), s. 6. 
stąpieniu fakt przeciagającego się kryzysu gospodarczego, groźbę narastającego faszyzmu i antysemityzmu. Uznał, że problemy ludności wyznania mojżeszowego rozwiąże planowany Światowy Kongres Żydowski. Skrytykował rząd brytyjski za politykę mandatową w Palestynie. Ewentualne porozumienie w niej z Arabami uznał za bezcelowe. Potępił siły odśrodkowe w ruchu syjonistycznym, co było wymierzone głównie w syjonistów-rewizjonistów. Konferencja przyjęła rezolucje, że OSMZiŚl jest częścią ŚZwOS, o zwiększeniu pracy na rzecz funduszy narodowych, poparciu dla oświaty narodowej rozwijanej w ramach organizacji „Tarbutu”, przyszłe państwo żydowskie miało objąć Palestynę i Transjordanię. Prezesem Rady Partyjnej wybrano O. A. Thona, a Centralnego Komitetu L. Salpetera ${ }^{42}$.

W dniach 10-11 lutego 1935 r. odbyła się w Krakowie XVI Konferencja Krajowa OSMZiŚl. Wiele uwagi poświęcono sytuacji panującej w organizacjach młodzieżowych i kwestii przeszkolenia zawodowego w związku z emigracją do Palestyny. Zaapelowano do ŚZwOS o podjęcie działań w celu zlikwidowania kryzysu w Komitecie Wykonawczym ŚSS zdominowanym przez lewicę. I. Schwartzbart skrytykował sytuację panującą w ruchu ogólnosyjonistycznym w byłym zaborze rosyjskim i wskazał na panujący konflikt z OSwP. W rezolucjach potępiono politykę Wielkiej Brytanii w Palestynie i ograniczenie imigracji do niej Żydów. Prezesem honorowym rady został wybrany O. A. Thon, a egzekutywy L. Salpeter ${ }^{43}$.

Wraz z wielkim kryzysem gospodarczym oraz radykalizacją ludności żydowskiej i syjonistów, zaczęła narastać tendencja do utworzenia odrębnej struktury przez syjonistów-rewizjonistów. Na przełomie 1930 i $1931 \mathrm{r}$. ujawniły się zamiary utworzenia odrębnej partii. 2 stycznia 1931 r. na konferencji syjonistów-rewizjonistów dzielnicy krakowskiej zapowiedziano powołanie w Krakowie centrali ogólnopolskiej oraz zakładanie samodzielnych komitetów lokalnych partii ${ }^{44}$. Ostatecznie centrala Organizacji Syjonistów-Rewizjonistów w Polsce powstała w Warszawie. Krakowska centrala

${ }^{42}$ ANK, Urząd Wojewódzki Krakowski, sygn. 29/206/551 (dawna sygn. UWKr 282), k. 58; „Nowy Dziennik” 1934, nr 51 (20 lutego), s. 1, 12; nr 52 (21 lutego), s. 4; nr 62 (3 marca), s. 7; nr 63 (4 marca), s. 6.

${ }^{43}$ ANK, Urząd Wojewódzki Krakowski, sygn. 29/206/554 (dawna sygn. UWKr 285), k. 57; „Nowy Dziennik” 1935, nr 42 (11 lutego), s. 1-2; nr 43 (12 lutego), s. 6; nr 46 (15 lutego), s. 4.

${ }^{44}$ ANK, Urząd Wojewódzki Krakowski, sygn. 29/206/544 (dawna sygn. UWKr 275), k. 21. 
dzielnicowa pełniła funkcję lokalnego koordynatora i zerwała współpracę z OSMZiŚl.

Nie są znane przebiegi obrad II i III konferencji dzielnicowej syjonistów-rewizjonistów z 1932 i 1933 r. Nowa partia przyjęła na początku 1934 r. nazwę US-RMZiŚl. Na IV konferencji krajowej partii 4 marca 1934 r. w Krakowie omawiano sprawy organizacyjne i zapowiadano walkę z hitleryzmem. Od 1932 r. nastąpił szybki rozwój partii w dzielnicy krakowskiej. Prezesem dzielnicowej centrali został dr J. B. Damm. Wobec powołania go do światowej egzekutywy partii 10 lutego $1934 \mathrm{r}$. Rada Partyjna US-RMZiŚl wybrała tymczasowo na jego miejsce Abrahama Rosenmanna ${ }^{45}$.

Mizrachi z powodu zerwania współpracy z Organizacją Syjonistyczną zbliżała się od drugiej połowy lat 20. do syjonistów-rewizjonistów. 13 grudnia 1931 r. obradowała w Krakowie IV Konferencja Krajowa Mizrachi Małopolski Zachodniej i Śląska, na której ujawniła się tendencja do nawiązania współpracy z Agudas Israel. Omawiano wychowanie młodzieży w duchu narodowo-religijnym. Postulowano swobodną emigrację do Palestyny, popieranie partyjnego funduszu narodowego i ruchu chalucowego, zakładanie odrębnych bożnic. Prezesem partii wybrano S. Hirschfelda. Ścisła współpraca Mizrachi z syjonistami-rewizjonistami nastąpiła w 1933 r., gdy obie partie zmierzały do zerwania z Komitetem Wykonawczym ŚOS ${ }^{46}$.

Na przełomie lat 20. i 30. Nastapiły zmiany w syjonistycznych partiach robotniczych. Na X Konferencji Krajowej Hitachduthu Małopolski Zachodniej i Śląska 26 października 1930 r. w Krakowie domagano się skrystalizowania programu partii i tworzenia jej nowych oddziałów ${ }^{47}$. Na XI konferencji krajowej Hitachduth dzielnicy krakowskiej 10 października 1931 r. w Krakowie omawiano sprawę zjednoczenia partii z Poalej Syjon-Prawica. Domagano się równouprawnienia języka jidysz z hebrajskim oraz rozwoju ideologii syjonistyczno-socjalistycznej. Prezesem partii wybrano O. Menasche ${ }^{48}$.

${ }^{45}$ ANK, Urząd Wojewódzki Krakowski, sygn. 29/206/554 (dawna sygn. UWKr 285), k. 58; ,Trybuna Narodowa” 1934, nr 4 (9 marca), s. 1; nr 5 (16 marca), s. 6.

${ }^{46}$ ANK, Urząd Wojewódzki Krakowski, sygn. 29/206/544 (dawna sygn. UWKr 275), k. 287; „Nowy Dziennik” 1931, nr 340 (19 grudnia), s. 11-12; nr 341 (20 grudnia), s. 11.

${ }^{47}$ „Nowy Dziennik” 1930, nr 289 (1 listopada), s. 12.

${ }^{48}$ ANK, Urząd Wojewódzki Krakowski, sygn. 29/206/544 (dawna sygn. UWKr 275), k. 264. 
X Światowa Konferencja Poalej Syjon-Prawicy i VI Światowa Konferencja Hitachduth obradujące wspólnie w Gdańsku w sierpniu 1932 r. podjęły decyzję o połączeniu obu partii. W dzielnicy krakowskiej ich wpływy były zbliżone. Hitachduth dążył do zjednoczenia na zasadach autonomicznych. Obradująca w dniach 3-4 lutego 1934 r. Konferencja Krajowa Hitachduthu uchwaliła zjednoczenie partii z Poalej Syjon-Prawicą i utworzenie Syjonistyczno-Socjalistycznej Partii Hitachduth - Poalej Syjon-Prawica Małopolski Zachodniej i Śląska. Na czele nowej partii stanął G. A. Terło ${ }^{49}$. Część Hitachduth nie uznała połączenia partii i kontynuowała samodzielną działalność.

W kwietniu 1935 r. W. Żabotyński podjął decyzję o wystąpieniu Organizacji Syjonistów-Rewizjonistów z ŚOS.

Przełomowe znaczenie dla OSMZiŚl miała jej XVII konferencja krajowa. W lutym 1936 r. na łamach „Nowego Dziennika” trwała dyskusja o sytuacji w ruchu syjonistycznym. L. Salpeter domagał się likwidacji partii i frakcji. Uznał, że unifikacja ogólnych syjonistów zależy od ŚZwOS oraz podkreślił kilkunastoletnie dążenie centrali krakowskiej do zjednoczenia obozu narodowego ${ }^{50}$. I. Schwartzbart zajął stanowisko pesymistyczne, stwierdził, że rola ogólnych syjonistów w ruchu narodowym maleje, ale wierzył w możliwość ich unifikacji. Poparł on zapowiedziane przez XIX Kongres Syjonistyczny tworzenie jednolitych organizacji krajowych ${ }^{51}$. Podobne stanowisko zajął C. Hilfstein, który uznał, że różnice w ramach ŚOS są taktyczne. Nie popierał on jednak powstania jednolitych organizacji krajowych, bowiem spowodowałoby to tylko walki wewnętrzne między byłymi partiami ${ }^{52}$. Dr Abraham Chomet nie przewidywał możliwości porozumienia między strukturami ogólnosyjonistycznymi, a dążenie do tworzenia jednolitych organizacji uznał za szkodliwe, bowiem najpierw należałoby rozwiązać istniejące partie i frakcje ${ }^{53}$. Joachim Neiger potępił frakcjonizm w ruchu syjonistycznym i domagał się przywrócenia jednolitego frontu ogólnosyjonistycznego. Tworzenie jednolitych organizacji krajowych uwa-

${ }^{49}$ ANK, Urząd Wojewódzki Krakowski, sygn. 29/206/551 (dawna sygn. UWKr 551), k. 78; „Nowy Dziennik” 1934, nr 38 (7 lutego), s. 4.

${ }^{50}$ „Nowy Dziennik” 1936, nr 47 (16 lutego), s. 4.

51 „Nowy Dziennik” 1936, nr 49 (18 lutego), s. 4.

52 „Nowy Dziennik” 1936, nr 48 (17 lutego), s. 3

53 „Nowy Dziennik” 1936, nr 51 (20 lutego), s. 6. 
żał za błędne, a zjednoczenie ogólnych syjonistów należałoby rozpocząć od organizacji młodzieżowych ${ }^{54}$.

W czasie dyskusji prasowej ujawniła się, powstała w styczniu 1936 r., w łonie OSMZiŚl opozycyjna grupa - Blok Jedności Syjonistycznej, której przywódcą był dr Kalman Stein. Frakcja domagała się, aby ogólny syjonizm miał charakter ponadpartyjny i żądała uznania jego socjalnych treści, ale wypowiedziała się przeciwko przekształceniu go w partię jednej warstwy społecznej. Postulowała realizację zasad sprawiedliwości społecznej w Palestynie - poprawy położenia warstw niższych, ale odżegnywała się od walki klasowej. Blok Jedności Syjonistycznej domagał się zjednoczenia partii ogólnosyjonistycznych oraz popierał tworzenie jednolitych krajowych organizacji syjonistycznych ${ }^{55}$.

Powstanie Bloku Jedności Syjonistycznej wiązało się prawdopodobnie z działaniami OSwP dążącej do rozbicia spoistej do tej pory OSMZiŚl.

23 lutego 1936 r. obradowała w Krakowie XVII Konferencja Krajowa OSMZiŚl. O. A. Thon stwierdził, że działalność frakcji w ramach partii jest naturalna, a niebezpieczeństwo istniałoby dopiero wówczas, gdyby jedna z nich chciała zlikwidować drugą. Wskazał, że partia powinna walczyć głównie o kulturę narodową, ale doceniać także sprawy ekonomiczne. I. Schwartzbart uznał, że Organizacja Syjonistyczna nie może być partią na tyle tolerancyjną, aby doprowadzić do anarchii, co było wymierzone w Blok Jedności Syjonistycznej. Domagał się poparcia dla ŚZwOS. Protestowano przeciwko złemu położeniu materialnemu Żydów w Polsce i ich dyskryminacji. Wyrażono poparcie dla emigracji zasłużonych syjonistów i robotników z dzielnicy krakowskiej. Domagano się rozbudowy ośrodków chalucowych w Małopolsce Zachodniej. Poparto rozwój kultury i oświaty narodowej w ramach organizacji „Tarbut”. Pragnąc doprowadzić do kompromisu programowego z frakcją opozycyjną, konferencja podjęła uchwałe, że podstawę ekonomiczną odbudowy państwa żydowskiego stanowi wieś, w przeciwieństwie do wcześniejszych oświadczeń o równym poparciu kolonizacji wiejskiej chaluców i miejskiej stanu średniego. Prezesem honorowym partii wybrano O. A. Thona, a egzekutywy C. Hilfsteina. Aby zapobiec rozbiciu, w składzie Centralnego Komitetu partii znalazł się K. Stein ${ }^{56}$.

54 „Nowy Dziennik” 1936, nr 52 (21 lutego), s. 4.

55 „Nowy Dziennik” 1936, nr 50 (19 lutego), s. 4.

${ }^{56}$ „Nowy Dziennik” 1936, nr 55 (24 lutego), s. 2-3; nr 56 (25 lutego), s. 6-7; nr 57 (26 lutego), s. 15; nr 59 (28 lutego), s. 8; nr 65 (5 marca), s. 6; nr 66 (6 marca), s. 8. 
14 lutego 1937 r. obradowała w Krakowie XVIII Konferencja Krajowa OSMZiŚSl. 11 listopada 1936 r. zmarł O. A. Thon, co wpłynęło na osłabienie jedności partii. Na zjeździe omawiano podjęcie działań zmierzających do zjednoczenia partii syjonistycznych w Polsce. Goszczący przedstawiciel Organizacji Ogólnych Syjonistów w Polsce (partia powstała w 1935 r. po rozłamie w OSwP) inż. Jakub Thon potwierdził gotowość do unifikacji. I. Schwartzbart podkreślił rolę ŚZwOS i wskazał na krytyczny stosunek do działań opozycji wewnątrz partii. Na poprzedniej konferencji skutecznie przeciwstawił się jej rozpadowi dr Samuel Liebeskind. Przywódca Bloku Jedności Syjonistycznej K. Stein mówił o rozbiciu partii. Konferencja domagała się stworzenia jednolitego frontu ogólnożydowskiego. Potwierdzono przekonanie o panującej trudnej sytuacji ekonomicznej i politycznej Żydów w Polsce na skutek fali antysemityzmu. Nowym prezesem Centralnego Komitetu wybrano C. Hilfsteina, a zrezygnowano z powołania prezesa Rady Partyjnej ${ }^{57}$.

Obradująca 2 stycznia 1938 r. Rada Partyjna OSMZiŚl dokonała zmian w statucie partii, wśród których najważniejszą było zniesienie stanowisko prezesa stronnictwa ${ }^{58}$.

27 marca 1938 r. w Krakowie odbyła się XIX Konferencja Krajowa OSMZiŚl. Rozegrała się na niej walka między ogólnosyjonistyczną większością a opozycyjnym Blokiem Jedności Syjonistycznej. I. Schwartzbart wskazał na konieczność konsolidacji ŚOS. K. Stein domagał się podobnie jedności centrali światowej i ruchu syjonistycznego w Polsce. Podkreślał trudne położenie Żydów w Polsce i ich dyskryminację. Przedstawiciel opozycji Feliks Lach poinformował o wystapieniu Bloku Jedności Syjonistycznej ze ŚZwOS, co prowadziłoby do rozbicia partii w dzielnicy krakowskiej. Konferencja zakończyła się sukcesem większości ogólnosyjonistycznej. Prezesem egzekutywy partii wybrano I. Schwartz$\operatorname{barta}^{59}$.

${ }^{57}$ ANK, Urząd Wojewódzki Krakowski, sygn. 29/206/559 (dawna sygn. UWKr 290), k. 45; „Nowy Dziennik” 1936, nr 312 (12 listopada), s. 1; „Nowy Dziennik” 1937, nr 46 (15 lutego), s. 1-2; nr 48 (17 lutego), s. 10; nr 55 (24 lutego), s. 11.

58 „Nowy Dziennik” 1938, nr 3 (3 stycznia), s. 12.

${ }^{59}$ ANK, Starostwo Grodzkie Krakowskie, sygn. 29/218/134 (dawna sygn. StGKr 134), k. 23; ANK, Urząd Wojewódzki Krakowski, sygn. 29/206/561 (dawna sygn. UWKr 292), k. 83; „Nowy Dziennik” 1938, nr 87 (28 marca), s. 3-4. 
Delegaci Bloku Jedności Syjonistycznej na XVIII konferencję uchwalili 28 kwietnia rezolucję o pozostaniu w OSMZiŚl i realizowaniu w jej ramach swych celów ${ }^{60}$.

W dniach 25-26 marca 1939 r. odbyła się w Krakowie XX Konferencja Krajowa OSMZiŚl. S. Feldblum podkreślił brak nadziei na odbudowę państwa żydowskiego, L. Salpeter nawoływał do ofiarności na rzecz funduszy narodowych mimo istniejącej sytuacji, a I. Schwartzbart zapowiadał kolejny raz unifikację ruchu ogólnosyjonistycznego w Polsce. Domagano się rzeczywistego równouprawnienia Żydów w Polsce. W czasie obrad ujawnił swą działalność Blok Jedności Syjonistycznej. Prezesem Centralnego Komitetu wybrano ponownie I. Schwartzbarta ${ }^{61}$.

Dnia 21 czerwca 1936 r. odbyła się VI Konferencja Krajowa US-RMZiŚl. Dyskutowano o potrzebie unifikacji syjonistów-rewizjonistów. Prezesem dzielnicowym partii wybrano Jakuba Schächtera ${ }^{62}$. Na VII Konferencji Krajowej US-RMZiŚ1 w Krakowie w dniach 10-11 października 1937 r. protestowano przeciwko planowi podziału Palestyny między Żydów i Arabów oraz osiedlaniu się tych drugich w Palestynie. Potępiono panujący antysemityzm w Polsce. Prezesem dzielnicowym partii wybrano dr. Jana Badera ${ }^{63}$.

W drugiej połowie lat 30. niewielką aktywność przejawiała Mizrachi. W dniach 4-5 października 1936 r. odbyła się w Krakowie VII konferencja krajowa partii. Domagano się wzrostu ofiarności na rzecz funduszy narodowych i odbudowy państwa żydowskiego. Protestowano przeciwko ograniczeniu emigracji do Palestyny przez brytyjskie władze mandatowe. Jej prezesem dzielnicowym wybrano S. Hirschfelda, a egzekutywy Eliasza Markusa $^{64}$.

W tym okresie nastapiły przemiany w lewicowych partiach syjonistycznych. Na konferencji Syjonistycznej Partii Pracy Hitachduth Małopolski Zachodniej i Śląska 9 lutego 1936 r. w Krakowie jej kierownictwo potwier-

${ }^{60}$ „Nowy Dziennik” 1938, nr 112 (24 kwietnia), s. 13.

${ }^{61}$ ANK, Urząd Wojewódzki Krakowski, sygn. 29/206/562 (dawna sygn. UWKr 293), k. 87; „Nowy Dziennik” 1939, nr 86 (27 marca), s. 3; nr 87 (28 marca), s. 9; nr 91 (31 marca), s. $15,186$.

62 „Trybuna Narodowa” 1936, nr 25, s. 4.

${ }^{63}$ ANK, Urząd Wojewódzki Krakowski, sygn. 29/206/559 (dawna sygn. UWKr 290), k. 187; „,Trybuna Narodowa” 1937, nr 40, s. 5-6.

${ }^{64}$ ANK, Urząd Wojewódzki Krakowski, sygn. 29/206/556 (dawna sygn. UWKr 287), k. 21 . 
dziło samodzielność partii. Jednak wobec nacisków oddolnych 1 marca 1936 r. doszło do połączenia większości partii z Syjonistyczno-Socjalistyczną Partią Hitachduth - Poalej Syjon-Prawica i utworzenia Syjonistycznej Partii Pracy Hitachduth Małopolski Zachodniej i Śląska, której przywódcą był Ozjasz Spiro. Zjednoczenia nie uznała część członków Syjonistycznej Partii Pracy Hitachduth, ale w lutym 1937 r. szczątkowa partia uległa samorozwiązaniu z powodu wystąpienia członków ${ }^{65}$.

Władze OSMZ (od 1920 r. OSMZiŚl) pełniły od 1919 r. rolę dzielnicowej centrali syjonistycznej w Krakowie. Początkowo skupiała ona wszystkie nurty żydowskiego ruchu narodowego z wyjątkiem Poalej Syjon-Prawicy, pomimo istnienia formalnie samodzielnych struktur dzielnicowych Mizrachi i Hitachduth. Decydującą rolę w działalności centrali do 1936 r. odgrywał O. A. Thon, choć od 1926 r. ulegała ona osłabieniu. W 1925 r. powstała samodzielna dzielnicowa struktura władzy Mizrachi, a w 1927 r. Hitachduth, co dało początek odrębnym centralom. W 1926 r. ujawniła się w ramach OSMZiŚl grupa syjonistów-rewizjonistów, która w 1931 r. przekształciła się w samodzielną partię z własną centralą dzielnicową. W $1936 \mathrm{r}$. w ramach OSMZiŚl powstał radykalny Blok Jedności Syjonistycznej. Wobec słabości obu partii Hitachduth i Poalej Syjon-Prawicy w latach 1934-1936 nastapiło ich połączenie.

Od 1919 r. podejmowano próby zjednoczenia central dzielnicowych krakowskiej i warszawskiej, a od 1924 r. wszystkich central ogólnosyjonistycznych działających w II Rzeczypospolitej Polskiej.

\section{BIBLIOGRAFIA}

\section{Źródla rękopiśmienne}

Archiwum Akt Nowych w Warszawie

Ministerstwo Spraw Wewnętrznych w Warszawie, sygn. 961, 962, 1062.

Archiwum Narodowe w Krakowie

Starostwo Grodzkie Krakowskie, sygn. 29/218/108 (dawna sygn. StGKr 108), 29/218/133 (dawna sygn. StGKr 133), 29/218/134 (dawna sygn. StGKr 134).

Urząd Wojewódzki Krakowski, sygn. 29/206/534 (dawna sygn. UWKr 265), 29/206/535 (dawna sygn. UWKr 266), 29/206/540 (dawna sygn. UWKr 271), 29/206/541 (daw-

${ }^{65}$ Ibidem, k. 44, 71. 
na sygn. UWKr 272), 29/206/544 (dawna sygn. UWKr 275), 29/206/546 (dawna sygn. UWKr 277), 29/206/548 (dawna sygn. UWKr 279), 29/206/551 (dawna sygn. UWKr 282), 29/206/554 (dawna sygn. UWKr 285), 29/206/556 (dawna sygn. UWKr 287), 29/206/559 (dawna sygn. UWKr 290), 29/206/561 (dawna sygn. UWKr 292), 29/206/562 (dawna sygn. UWKr 293).

\section{Prasa}

„Nasz Przegląd” 1924, nr 266.

„Nowy Dziennik” 1919, nr 79, 86-88, 93; 1921, nr 84, 87, 104, 292, 293; 1924, nr 161, 212, 277-279; 1925, nr 59, 118, 121, 125, 126; 1926, nr 4-6, 140, 146, 166, 245, 247-249; 1927, nr 68, 290, 308; 1928, nr 6, 294-298, 302; 1929, nr 149, 153, 298; 1930, nr 8-13, 25-27, 289; 1931, nr 56, 59, 60, 340, 341; 1932, nr 8, 9, 14, 15, 21; 1933, nr 128, 134; 1934, nr 18, 38, 51, 52, 62, 63; 1935, nr 42, 43, 46; 1936, nr 47-52, 55-57, 59, 66, 312; 1937, nr 46, 48, 55; 1938, nr 3, 87, 112; 1939, nr 86, 87, 97.

„Trybuna Narodowa” 1934, nr 4, 5; 1936, nr 25; 1937, nr 40.

\section{Opracowania}

Friedman Filip: Rozwój żydowskiego ruchu narodowego w Galicji i walka o prawa narodowe. W: Żydzi w Polsce odrodzonej. Działalność społeczna, gospodarcza, oświatowa $i$ kulturalna, t. 1. Red. Ignacy Schiper, Arjeh Tartakower, Aleksander Hafftka. Warszawa: Żydzi w Polsce Odrodzonej [1932], s. 396-399.

Friedman Filip: Żydowski ruch robotniczy w Galicji. W: Żydzi w Polsce Odrodzonej. Działalność społeczna, gospodarcza, oświatowa, kulturalna, t. 1. Red. Ignacy Schiper, Arjeh Tartakower, Aleksander Hafftka. Warszawa: Żydzi w Polsce Odrodzonej [1932], s. 399-401.

Jaworski Wojciech: Struktura i wpływy syjonistycznych organizacji politycznych $w$ Polsce w latach 1918-1939. Warszawa: Oficyna Wydawnicza Rytm, 1996.

Jaworski Wojciech: Syjoniści wobec rzadu polskiego w okresie międzywojennym. Sosnowiec: Wojciech Jaworski, 2002.

Mendelsohn Ezra: Zionizm in Poland. The formative years 1915-1926. New Haven-London: Yale University Press, 1981.

Schiper Ignacy: Dzieje syjonizmu na ziemiach polskich (do 1918 r.). W: Żydzi w Polsce Odrodzonej. Działalność społeczna, gospodarcza, oświatowa, kulturalna, t. 1. Red. Ignacy Schiper, Arjeh Tartakower, Aleksander Hafftka. Warszawa: Żydzi w Polsce Odrodzonej [1932], s. 518-530.

Schiper Ignacy: Żydzi galicyjscy w ostatnim roku pożogi wojennej. W: Żydzi w Polsce Odrodzonej. Działalność społeczna, gospodarcza, oświatowa, kulturalna, t. 1. Red. Ignacy Schiper, Arjeh Tartakower, Aleksander Hafftka. Warszawa: Żydzi w Polsce Odrodzonej [1932], s. 419-422.

Walicki Jacek: Ruch syjonistyczny w Polsce w latach 1926-1930. Łódź: Uniwersytet Łódzki. Centrum Badań Żydowskich, 2005. 


\section{PODSUMOWANIE Centrale syjonistyczne w Krakowie (1919-1939)}

Władze Organizacji Syjonistycznej Małopolski Zachodniej (od 1920 r. Organizacji Syjonistycznej Małopolski Zachodniej i Śląska) pełniły od 1919 r. rolę dzielnicowej centrali syjonistycznej w Krakowie. Obejmowała ona początkowo swym działaniem byłą Galicję Zachodnią po rzekę San na wschodzie. W 1920 r. obszar działania centrali powiększył się o część przyłączonego do Polski Śląska Cieszyńskiego, a w 1922 r. część Górnego Śląska. Początkowo skupiała ona wszystkie nurty żydowskiego ruchu narodowego z wyjątkiem partii robotniczej Poalej Syjon-Prawicy. Decydującą rolę w działalności centrali do 1936 r. odgrywał postępowy rabin Ozjasz Abraham Thon, choć od 1926 r. ulegała ona osłabieniu. W 1925 r. powstała samodzielna dzielnicowa struktura władzy ortodoksyjno-syjonistycznej partii Mizrachi, a w 1927 r. lewicowej Hitachduth, co dało początek odrębnym centralom. W 1926 r. ujawniła się w ramach Organizacji Syjonistycznej Małopolski Zachodniej i Śląska grupa syjonistów-rewizjonistów, która w 1931 r. przekształciła się w samodzielną partię z własną centralą dzielnicową. Wobec słabości obu partii lewicowych Hitachduth i Poalej Syjon-Prawicy w latach 1934-1936 nastapiło ich połączenie.

\section{SUMMARY \\ Zionist headquarters in Krakow (1919-1939)}

The authorities of the Zionist Organisation of Western Malopolska (from 1920 the Zionist Organisation of Western Malopolska and Silesia) fulfilled the role from 1919 of Zionist headquarters in Krakow. Initially, its activities covered the area of Western Galicia to the River San in the east. In 1920, the area of activity was enlarged to include the part of Cieszyn Silesia added to Poland, and in 1922 part of Upper Silesia. In the beginning, it focused on all Jewish national movements, with the exception of the Poalej Zion-Right workers' party. Rabbi Abraham Ozjasz Thon played a central role in the activities of the headquarters until 1936, although after 1926 his position was weakened. In 1925, an independent regional leadership structure was established for the Mizrachi Orthodox-Zionist party, and in 1927 for the left-wing Hitachduth party, which led to the beginning of separate headquarters. In 1926, a group of Zionist-revisionists appeared within the Zionist Organisation of Western Malopolska and Silesia, which in 1931 transformed into an independent party with its own headquarters. Due to the weakness of both left-wing parties, Hitachduth and Poalej Zion-Right in the years 1934-1936, their merger took place.

SŁOWA KLUCZOWE: syjonizm, centrale syjonistyczne, Kraków, 1918-1939

KEY WORDS: Zionism, Zionist headquarters, Krakow, 1918-1939 